\title{
KOMUNIKASI SIMBOL IDEOLOGI FRAKSI PARTAI KEADILAN SEJAHTERA
}

\author{
Heni Nuraeni Zaenudin \\ Stisipol Chandra Dimuka Palembang Program Studi Ilmu Komunikasi \\ Jl. Swadaya Sekip Ujung Palembang Tlp (0711) 811542 /7900302 Fax (0711) 316020 \\ email : heni.hakam@yahoo.com, HP 081214436831 \\ Naskah dikirim tanggal 3 Desember 2012, disetujui tanggal 12 Desember 2012
}

\begin{abstract}
COMMUNICATION SYMBOLS IDEOLOGY FRAKSI PARTAI KEADILAN SEJAHTERA
\end{abstract}

\begin{abstract}
PKS believes that the executive, legislative and judicial branches in Indonesia into a den of corruption, so that the necessary steps for the realization of reforms in the form of cleaning goverment. Although the climate of freedom and openness of the field, but the partisan tradition in a modern, professional and responsible in this country is not yet stable. A number of parties were impressive dominated by an elite, rather than driven by a common ideology which is the basis and the action. Researchers integrate the theory of phenomenology and symbolic interactionism theory and opinion-constructivist approach and qualitative research methods with a tradition of phenomenological research, or interpretive paradigm (interpretive paradigm). Implementation of ideological symbols FPKS communicated both verbally and nonverbally. Symbols FPKS verbal ideology in the West Java Provincial Parliament in the form of implementing the slogan Clean, Caring, Professional, Da'wa Party, Justice, Prosperity, Tafsi Coat, while translating ideology in the form of non-verbal symbols, among others, the hijab is an identity for Muslim politician, Beard Symbol of Sunnah Share FPKS, ban on smoking in FPKS Haram, Music Murotalan Strains Air Heart, Jewelry not intended for men, Time Inconsistency (Polikronik Time)
\end{abstract}

Keywords: Fraksi Partai Keadilan Sejahtera, Symbolic Interaction. Verbal and Non-Verbal Communication

\begin{abstract}
Abstrak
PKS berpandangan bahwa lembaga eksekutif, legislatif serta yudikatif di Indonesia menjadi sarang KKN, sehingga perlu langkah berupa reformasi untuk terwujudnya cleaning government. Meski iklim kebebasan dan keterbukaan semakin lapang, namun tradisi berpartai secara modern, profesional dan bertanggung jawab di negeri ini masih belum mantap. Sejumlah partai politik masih didominasi oleh sekelompok elit, ketimbang digerakkan oleh ideologi bersama yang menjadi basis dan aksinya. Peneliti mengintegrasikan teori fenomenologi dan teori interaksionisme simbolik dan menggunakan pendekatan subjektif-konstruktivis serta metode penelitian kualitatif dengan tradisi penelitian fenomenologi, atau paradigma interpretif
\end{abstract}


(interpretive paradigm). Implementasi simbol ideologi FPKS dikomunikasikan baik secara verbal dan nonverbal. Simbol ideologi verbal FPKS di DPRD Provinsi Jawa Barat yang mengimplementasikan slogan "Bersih, Peduli, Profesional, Partai Dakwah, Keadilan, Sejahtera, Tafsi Lambang," Sedangkan simbol ideologi nonverbal diterjemahkan antara lain dalam bentuk, jilbab Merupakan Identitas bagi Politikus Muslimah, Jenggot Simbol dari Sunnah Bagi FPKS, Larangan Haram terhadap Rokok di FPKS, Musik Murotalan Alunan Penyejuk Hati, Perhiasan Tidak Diperuntukkan Bagi Laki-Laki, Inkonsistensi Waktu (Waktu Polikronik).

Kata Kunci : Fraksi Partai Keadilan Sejahtera, Interaksi Simbolik. Komunikasi Verbal dan NonVerbal

\section{PENDAHULUAN}

Pada pemilu tahun 2009 Partai Keadilan Sejahtera menggunakan slogan "Bersih, Peduli dan Profesional". Slogan ini diperkuat lagi dengan visi PKS 2005-2010: "Menjadi Partai Dakwah yang Kokoh untuk Melayani dan Memimpin Bangsa". Dengan visi opsesif PKS 2005-2010 ini gerakan PKS ke depan berkonsentrasi pada dua agenda besar PKS yakni pengokohan jatidiri PKS sebagai partai dakwah dalam segala aspek dan peningkatan pelayanan dan peran PKS dalam kehidupan bermasyarakat, berbangsa, dan bernegara dalam berbagai bidang kehidupan. (Zaidi, 2007)

Para Kader PKS di legislatif berusaha untuk mengimplementasikan ideologi partai yang mereka anut seperti dalam slogan Bersih, peduli, dan profesional. Di tahun 2009 slogan ditambahkan dengan kata profesional dengan pertimbangan karena setelah pemilu di tahun 1999 kemudian 2004 Partai Keadilan Sejahtera lebih banyak dikenal oleh masyarakat banyak, ini bisa dibuktikan dengan perolehan suara pada pemilu yang pada akhirnya bisa mengantarkan para kadernya ke lembaga eksekutif dan legislatif. Dengan banyaknya kader yang terjun dalam ranah politik praktis serta birokrasi pemerintahan, PKS ingin menunjukkan bahwa mereka bisa bertindak secara profesional.

Jika dinisbahkan dengan teori Mead yaitu tentang manusia dan makna menyatakan, manusia di samping mampu memahami orang lain juga mampu memahami dirinya sendiri. Menurut Mead ini dikarenakan manusia ditunjang oleh penguasaan bahasa sebagai simbol dan isyarat. Jika menilik teori dari Blummer interaksi simbolik bertumpu pada tiga premis yaitu, (1) Manusia bertindak terhadap sesuatu berdasarkan makna-makna yang ada pada sesuatu bagi mereka, (2) Makna tersebut berasal dari "interaksi sosial seseorang dengan orang lain, dan (3) Makna-makna tersebut disempurnakan di saat proses interaksi berlangsung.(Sukidin, 2002) .

Tidak dapat dipungkiri setiap anggota legislatif di parlemen berusaha untuk mentransformasikan nilai-nilai dan ideologi yang mereka anut. Dalam kegiatan komunikasi politik dikenal istilah sosialisasi politik. R.S. Signal (dalam Harun dan Sumarno,2006), menyatakan bahwa sosialisasi politik adalah proses belajar yang terkait dengan norma politik yang dapat dialihkan dari suatu generasi ke generasi berikutnya untuk menerima suatu sistem poltik yang sedang berlangsung. Sedangkan menurut Robinson (dalam Sumarno dan Harun, 2006) menyatakan bahwa: "Sosialisasi politik merupakan proses perubahan perilaku yang berhubungan erat dengan proses belajar dalam proses ini terjadi penyetaraan pemahaman terhadap segala peristiwa politik" Jika dikaitkan dengan teori interaksi simbolik Charles Horton Cooley dalam Soeprapto (2001) menyebutkan semua interaksi antar individu manusia melibatkan pertukaran simbol. Salah satu strategi yang diterapkan yaitu ketika berinteraksi menggunakan simbol-simbol didalamnya berisi tanda-tanda, isyarat dan kata-kata bahasa yang bisa dipahami oleh mereka.

Penelitian ini berusaha untuk menggali permasalahan seputar pertanyaan: 
(1) Bagaimana anggota DPRD Fraksi PKS mengomunikasikan simbol ideologi yang mereka yakini baik yang sifatnya verbal maupun nonverbal di DPRD Provinsi Jawa Barat?; (2) Bagaimana anggota DPRD Fraksi PKS dalam mengonstruksikan pengertian dirinya sendiri, tindakan, objek, interaksi sosial, dan aksi kolektif?; (3) Bagaimana model proses komunikasi simbol ideologi FPKS di DPRD Provinsi Jawa Barat?

Penelitian ini bertujuan untuk mengungkap (1) Bagaimana anggota DPRD Fraksi PKS mengomunikasikan simbol ideologi yang mereka yakini baik yang sifatnya verbal maupun nonverbal di DPRD Provinsi Jawa Barat?; (2) Bagaimana anggota DPRD Fraksi PKS dalam mengonstruksikan pengertian dirinya sendiri, tindakan, objek, interaksi sosial, dan aksi kolektif?

\section{LANDASAN KONSEP}

Perspektif Interaksi Simbolik berusaha memahami perilaku manusia dari sudut pandang subjek. Perspektif ini menyarankan bahwa perilaku manusia harus dilihat sebagai proses yang memungkinkan manusia membentuk dan mengatur perilaku manusia dengan mempertimbangkan ekspektasi orang lain yang menjadi mitra interaksi mereka. Manusia bertindak hanya berdasarkan definisi atau penafsiran mereka atas objek-objek di sekeliling mereka. "Realitas" terletak pada mata yang melihat. Dalam pandangan Interaksi Simbolik, sebagaimana ditegaskan Blumer (dalam Orleans, Myron, 2000), proses sosial dalam kehidupan kelompoklah yang menciptakan dan menegaskan aturanaturan, bukan aturan-aturan yang menciptakan dan menegakkan kehidupan kelompok. Dalam konteks ini, makna dikonstruksikan dalam proses interaksi, dan proses tersebut bukanlah suatu medium netral yang memungkinkan kekuatan-kekuatan sosial memainkan perannya, melainkan justru merupakan subtansi sebenarnya dari organisasi sosial dan kekuatan sosial. Bagi penganut interaksi simbolik masyarakat adalah proses interaksi simbolik.

Teori Interaksi Simbolik berupaya mengonstruksikan pengertian tentang diri sendiri, tindakan, dan objek. Kemudian Herbert Blummer mengembangkan lebih lanjut gagasan Mead ini dalam lima konsep dasar, yaitu konsep diri, konsep tindakan, konsep objek, konsep interaksi sosial, dan konsep aksi kolektif. Penjelasannya sebagai berikut:

a. Konsep "diri" bahwa manusia bukan semata-mata organisme yang bergerak di bawah pengaruh stimulus baik dari luar maupun dari dalam. Melainkan "organisme yang sadar akan dirinya"(an organism having a self). Dalam berinteraksi dengan diri sendiri, manusia mampu memandang dirinya sebagai objek pikirannya, bergaul dan berinteraksi dengan dirinya sendiri. Sedangkan dalam bentuk tindakan, manusia melakukan dialog internal dalam menyusun konsep dan strategi untuk berhubungan dengan dunia yang berada di luar dirinya. Hasil interaksi internal ini akan bermuara pada tindakan.

b. Konsep "tindakan" yang dibentuk dalam dan melalui proses interaksi dengan dirinya sendiri. Tindakan manusia sendiri tidak semata-mata sebagai reaksi biologis, melainkan hasil konstruksinya. Karena itu, manusia sendiri tidak semata-mata sebagai reaksi biologis, melainkan hasil konstruksinya. Karena itu, manusia sendiri adalah konstruktor atas tindakannya, artinya sebelum bertindak manusia harus menentukan tujuan, menggambarkan arah tingkah lakunya, memperkirakan situasinya, mencatat dan menginterpretasikan tindakan orang lain serta mengecek dirinya. Mead menyimpulkan bahwa manusia dipandang sebagai organisasi aktif yang memiliki hak-hak terhadap objek yang dimodifikasikan. Tindakan yang dipandang sebagai tingkah laku dibentuk oleh pelaku, sebagai pengganti respon yang didapat dari dalam dirinya.

c. Konsep "objek". Manusia hidup di tengah-tengah objek, baik bersifat fisik atau sesuatu yang abstrak (konsep kebebasan atau filsafat). Inti dari objek itu tidak ditentukan oleh ciri-ciri 
interaksinya, melainkan oleh minat orang dan arti yang dikenakannya kepada objekobjek itu. Objek tersebut bagi Mead merupakan sesuatu yang bisa ditunjuk atau dirujuk, baik yang bersifat nyata maupun abstrak. Interaksionisme simbolik memandang kehidupan kelompok manusia adalah sebuah proses di mana objek-objek diciptakan, dikukuhkan, ditransformasikan bahkan dibuang. Kehidupan dan perilaku manusia secara pasti berubah sejalan perubahanperubahan yang terjadi di dalam dunia objek mereka.

d. Konsep "interaksi sosial”. Interaksi berarti bahwa setiap peserta memindahkan diri mereka secara mental ke dalam posisi orang lain. Manusia mencoba memahami maksud asli yang dilakukan orang lain, sehingga interaksi dan komunikasi dimungkinkan terjadi. Interaksi itu tidak hanya berlangsung melalui gerak-gerik saja, tetapi juga melalui simbol-simbol yang perlu dipahami dan dimengerti maknanya. Dalam interaksi simbolik, orang mengartikan dan menafsirkan gerak-gerik orang lain dan bertindak sesuai dengan maknanya itu.

e. Konsep "aksi kolektif" yang lahir dari perbuatan masing-masing peserta yang kemudian dicocokkan dan disesuaikan satu sama lain. Inti dari aksi kolektif adalah penyerasian dan peleburan arti, tujuan, pikiran, dan sikap. Karenanya interaksi sosial itu memerlukan banyak waktu untuk mencapai keserasian dan peleburan (Soeprapto dalam Antin, 2005).

Selanjutnya Herbert Blummer (1966) bahwa Interaksi Simbolik berusaha menjabarkan tiga pokok pikiran utama, yaitu pertama, bahwa manusia bertindak (act) terhadap sesuatu (thing) atas dasar makna (mean) yang dipunyai sesuatu baginya. Kedua, bahwa makna yang dipunyai sesuatu tersebut berasal atau muncul dari interaksi sosial antara seseorang dengan sesamanya. Ketiga, bahwa makna diperlukan atau diubah melalui proses penafsiran, yang digunakan orang dalam menghadapi sesuatu yang dijumpainya, artinya makna tidak begitu saja diterima tetapi ditafsirkan lebih dulu (Sunarto, 1993).

Dengan demikian manusia merupakan makhluk dinamis yang bisa bebas menentukan pilihan perilaku. Akan tetapi walaupun bebas, tetapi tetap terikat terhadap aturan dan hukum yang disepakati bersama atas dasar pemaknaan bersama. Adapun makna diciptakan dengan kesepakatan hasil interaksi dengan orang lain yang menjalankan peran masing-masing dalam lingkungannya. Kemudian makna-makna simbol yang telah disepakati dan disosialisasikan sehingga akan terjadi kesepakatan yang diakui oleh masyarakat dan terciptalah masyarakat yang menggunakan simbol-simbol yang disepakati bersama. Adapun proses penciptaan makna adalah sebagai berikut (Pohan, 2006):

(1) Hakekat "diri", dimana perspektif interaksi simbolik menonjolkan keagungan dan nilai individu atas pengaruh lainnya. Manusia dalam dirinya memiliki esensi kebudayaan, saling berhubungan, bermasyarakat dan memiliki buah pikiran. Tiap bentuk dari interaksi sosial itu dimulai dan berakhir dengan pertimbangan diri manusia. Lebih lanjut, Mead memberikan pemisahan diri ke dalam dua wujud yang menjadi asumsi dasar yang melandasi interaksi simbolis, yaitu "saya" $(I)$ dan "aku" (me). "Saya" (I) merupakan bagian yang aktif dari diri yang mampu menjalankan perilaku, sedangkan "aku" (me) mewujudkan dalam diri konsep tentang yang lain, seperti adat, pembatasan, sikap, dan nilai sosial. Proses pengalaman dan penafsiran adalah proses yang dinamakan penunjukan diri (self indication). "Saya" (I) dapat melalui stimulus, dan "aku" memungkinkan diri untuk mengamati kenyataan atau stimulus dengan konsepkonsep yang telah terbentuk dalam dirinya, seperti adat, kebudayaan, saling berhubungan, masyarakat dan buah pikiran. Diri tidak hanya berfungsi sebagai proses sosial tetapi juga dapat mencapai perkembangan diri individu yang menyeluruh melalui interaksi dengan orang lain.

(2) Hakekat "lambang", Mead memberikan 
antara dua tingkat interaksi, isyarat dan lambang. Blumer mengartikan tingkattingkat sebagai interaksi yang nonsimbolik dan interaksi yang simbolik. Bagi Mead dan Blumer perbedaan itu sama. Suatu isyarat yang bukan lambang, merupakan tindakan impulsive dan besifat sopan, dalam arti respons refleks. Sehingga yang menjadi inti dari interaksi nonsimbolik adalah tidak adanya proses interpretasi. Interaksi simbolik menurut adanya proses sosial intenal (dalam diri orang) yang berupa penunjukan diri serta penafsiran. Walaupun binatang mampu bertindak secara nonsimbolik, hanya manusialah yang mampu untuk berinteraksi secara simbolik. Seseorang akan memberikan responnya kepada tindakan orang lain atas dasar makna tindakan atau lambang. Mead dengan jelas menggambarkan bahwa arti lambang sepenuhnya tergantung kepada kemampuan individu dalam menempatkan dirinya dalam peranan orang lain. Umumnya warga masyarakat yang lebih luas dan bertanya akan dirinya sendiri, bagaimana orang lain akan memberikan respon seandainya ia berada pada situasi yang sama, fenomena ini dinamakan "pengambilan peran". Dengan kata lain arti lambang tesebut dimaknai dengan cara berempati dengan menjadi orang lain atau mengambil peran orang lain. Mengandaikan bagaimana "aku" memaknai sesuatu jika aku menjadi dia dan apa yang akan dilakukan.

(3) Hakekat "tindakan manusia", di mana adanya proses sosial internal penunjukan diri, perspektif interaksional memungkinkan individu untuk melihat diri sendiri sebagaimana orang lain melihat padanya. Supaya menjadi objek penafsiran diri sendiri dan melihat dalam penafsirannya persis seperti apa yang akan ia lakukan terhadap setiap objek lain, baik objek fisik maupun sosial. Dalam proses pengambilan peran, individu dapat mengambil peran orang lain (menurut Mead, disebut panggung permainan atau play stage). Melalui pengambilan inilah seorang individu, yang secara inhern adalah diri sosial, mencapai individualitasnya. Individu membentuk lingkungannya dan membangun "dirinya" sendiri pada waktu yang bersamaan. Jadi tindakan individu bukan semata-mata produk dari pengalaman masa silam dan stimuli lingkungan di masa lalu. Sampai derajat tertentu manusia dipandang oleh aliran interaksional sebagai penguasa yang menentukan nasibnya sendiri. Namun demikian, tanpa adanya orang lain, manusia akan terhambat dalam memperoleh dirinya dan kemanusiawiannya.

(4) Hakekat "tindakan sosial", di mana individu adalah perwujudan masyarakat berskala kecil yang tindakannya merupakan produk langsung dari satu bagian integral dari penafsiran diri serta pengambilan peran. Jadi individu merupakan wujud sosial, termasuk semua tekanan sosial kearah konformitas di samping kemampuannya untuk menyimpang dari tekanan penyesuaian diri dengan masyarakat. Sebagaimana menurut Blumer (1969) bahwa "Proses sosial dalam kehidupan kelompok itulah yang menciptakan peraturan, bukan sebaliknya peraturan yang membentuk dan memelihara kelompok itu". Oleh kerena peraturan tidaklah sama seperti ketentuan apriori, tetapi peraturan merupakan prinsip-prinsip yang berkembang selama menjalani kehidupan dan mencapai statusnya sebagai peraturan karena dilaksanakan secara berulangulang.

\section{METODE PENELITIAN}

Untuk mengungkap simbol ideologi FPKS di DPRD Jawa Barat menggunakan metode penelitian kualitatif dengan tradisi penelitian fenomenologi, atau yang disebut Thomas R. Lindlof (1995) sebagai paradigma interpretif (interpretive paradigm). Pendekatan yang dipilih adalah pendekatan atau perspektif subjektif-konstruktivis dengan menjelaskan makna perilaku dengan 
manafsirkan apa yang orang lakukan (Mulyana, 2002). Landasan teoretis dari penelitian kualitatif ini adalah fenomenologi, tindakan sosial dan interaksionisme simbolik. Fenomenologi dapat digunakan sebagai istilah generik untuk merujuk kepada semua pandangan ilmu sosial yang menempatkan kesadaran manusia dan makna subjektifnya sebagai fokus untuk memahami tindakan sosial (Mulyana, 2002). Bersamaan dengan perspektif fenomenologis, ditambahkan tindakan sosial dan interaksionisme simbolik. Teori tindakan sosial melihat perilaku subjekif yang bermakna yang ditujukan untuk memengaruhi atau berorientasi pada perilaku orang lain. Sedangkan interaksionisme simbolik berasumsi bahwa pengalaman manusia ditengahi oleh penafsiran. Prinsip metodologi interaksi simbolik adalah: (1) simbol dan interaksi itu menyatu. Tidak cukup bila kita merekam fakta. Kita juga harus mencari yang lebih jauh, yakni mencari konteks sehingga dapat ditangkap simbol dan maknanya, (2) Karena simbol dan makna itu tidak terlepas dari sikap pribadi, maka jatidiri subjek perlu dapat ditangkap, (3). Peneliti harus sekaligus mengaitkan antarsimbol dengan jatidiri dengan lingkungan yang menjadi hubungan sosialnya, (4) Merekam situasi yang menggambarkan simbol dan maknanya, bukan hanya merekam fakta sensual saja, (5) Metode-metode yang digunakan hendaknya mampu merefleksikan bantuk perilaku dan prosesnya, (6) Metode yang dipakai hendaknya mampu menangkap makna di balik interaksi. (Basrowi dan Sukidin, 2002)

Subjek penelitian ini adalah anggota legislatif Fraksi Partai Keadilan Sejahtera di Dewan Perwakilan Rakyat Daerah (DPRD) Provinsi Jawa Barat periode 2009-2014, yang dijadikan informan kunci (key informant) dengan melakukan wawancara mendalam (indepth interview) secara purposif, artinya pemilihan informan berdasarkan pertimbangan rasional peneliti bahwa informanlah yang memiliki otoritas dan kompetensi untuk memberikan informasi atau data sebagaimana yang diharapkan peneliti (Suprayogo dan Tobroni, 2001), termasuk terhadap informasi tambahan yang akan memberikan informasi, data dan keterangan tambahan dalam melengkapi dan mengaitkan hasil penemuan atau catatan kunci. Adapun informan kunci adalah anggota legislatif FPKS yang menjadi anggota DPRD Provinsi Jawa Barat Periode 2009-2014 serta anggota legislatif dari fraksi non-FPKS.

Jumlah informan primer yang dipilih adalah 8 orang. Subjek penelitian lainnya dalam penelitian ini adalah anggota DPRD dari fraksi non-PKS, wartawan, aktivis kampus yang datang ke DPRD Provinsi Jawa Barat, masyarakat yang megikuti kegiatan reses, dan Humas Provinsi Jawa Barat. Subjek-subjek penelitian ini diperlukan untuk memperkaya dan melengkapi data-data penelitian ini dan disebut informan sekunder. Untuk mendapatkan informasi yang diinginkan dari informan, peneliti harus membangun rapport dengan informan, khususnya informan primer. Rapport adalah hubungan antara peneliti dan subjek yang sudah melebur sehingga seolah-olah tidak ada lagi dinding pemisah di antara keduanya (Moleong, 2004).

Penelitian ini menggunakan teknik pengumpulan data triangulasi, yang bersifat menggabungkan berbagai teknik pengumpulan data untuk mendapatkan data dari sumber yang sama yakni studi dokumentasi, pengamatan, dan wawancara (Patton, 1980 dalam Sugiyono, 2008). Data yang diperoleh diolah melalui tahap editing dan tabulasi. Teknik analisis data yang akan digunakan dalam penelitian ini adalah tiga tahap analisis data dari Miles dan Huberman (1992), yaitu: reduksi data, penyajian (display) data, terakhir pengambilan kesimpulan dan verifikasi. Teknik pemeriksaaan keabsahan data menggunakan teknik triangulasi yakni pemeriksaan melalui sumber lainnya. Yaitu dengan membandingkan dan mengecek balik derajat kepercayaan suatu informasi yang diperoleh melalui waktu dan alat yang berbeda dalam metode kualitatif (Patton, 1987 dalam Moleong, 2004). Penelitian dilakukan di DPRD Provinsi Jawa Barat selama 4 bulan. 


\section{PEMBAHASAN}

Implementasi Slogan "Bersih, Peduli dan Profesional" di DPRD Provinsi Jawa Barat Pemimpin Harus Bersih

Slogan bersih, peduli dan profesional diartikan para kader PKS yang terjun di dunia politik praktis dengan memperlihatkan sikap jujur. Misalnya tidak terlibat dengan kasus korupsi. Dalam wawancara 20 Oktober 2009 dengan $\mathrm{Hj}$. Diah Nurwitasari, Dipl, Ing. para kader di parlemen bersiasat mengusung nilai-nilai kejujuran atau bersiasat dengan bersih dan transparan. Jika dahulu politik digambarkan syarat kepentingan elit dan penuh perebutan kekuasaan yang tidak sehat maka FPKS ingin mengubah citra tersebut. FPKS di DPRD Provinsi Jawa Barat ingin menunjukkan bahwa politik akan berpihak pada kepentingan masyarakat. Ketika kader PKS terjun di dunia politik praktis mereka berusaha mencerminkan sikap melayani pada masyarakat. Dalam Islam diajarkan seorang pemimpin adalah seorang pelayan ummah.

Pertemuan penulis dengan wakil ketua III DPRD Jawa Barat dari Fraksi PKS, Nur Supriyanto pada tanggal 20 Oktober 2009, mengatakan :

"Waktu masih Partai Keadilan dengan
suara 1,4 persen, kami ingin
menunjukkan bahwa kami adalah
partai yang bersih, kita juga harus
peduli dengan kebutuhan masyarakat.
Tetapi ketika partai melewati
electoral treshold para kader harus
bekerja secara profesional karena kita
akan melayani umat yang lebih besar."

Eka Hadian anggota legislatif dari FPKS periode 2009-2014 (wawancara Kamis tanggal 9 Oktober 2009) mengatakan :

\footnotetext{
"Ada kebiasaan-kebiasaan menerima gratifikasi, yang kalau menurut saya itu sebaiknya tidak diterima tetapi menurut yang lainnya sah-sah saja. Melihat hal tersebut saya banyak mencotohkan dengan sikap saya, tidak perlu dengan lisan. Apabila ada
}

permasalahan yang saya kurang paham maka akan saya konsultasikan kepada dewan syuro di tingkat daerah, wilayah dan pusat. Dewan syuro bertujuan untuk mendiskusikan hal-hal yang meragukan. Misalnya masalah keuangan yang berkenaan dengan uang yang boleh diterima dan uang yang tidak boleh diterima."

Para Kader yang sekarang menjadi anggota dewan periode 2009-2012 sedikit demi sedikit ingin membenahi sistem birokrasi serta manajemen keuangan yang kurang sehat. Menurut Lalu Suryade selama perjalanan sepuluh tahun menjadi anggota legislatif, kinerja orang-orang di parlemen masih jauh dari kesan ideal. Kesemua itu memengaruhi persepsi serta tendensi dari kinerja anggota dewan. Lalu Suryade, dalam wawancara pada tanggal 12 Oktober 2009 menggambarkan kinerja anggota dewan yang belum ideal sebagai berikut :

"Dalam kunjungan kerja setiap
anggota dewan harus diberikan
insentif. Misal: uang saku. Maka dari
itu anggota dewan di parlemen lebih
memilih melakukan kunjungan-
kunjungan daripada rapat di DPRD.
Padahal kunjungan anggota dewan
lebih menguras anggaran karena
banyak budget yang harus disiapkan.
Kebiasaan tersebut dikritikpun susah
karena yang membuat peraturan
tersebut adalah pemerintah pusat.
Kunjungan-kunjungan tersebut
menyedot waktu mereka yang
seharusnya lebih diefektifkan pada
rapat komisi."

Lalu Suryade berargumen jika anggota dewan tidak memiliki kinerja kerja yang ideal karena ia memaknakan perilaku tersebut berdasarkan interaksi sosial dirinya dengan orang lain. Asumsi tersebut dikuatkan berdasarkan pengalamannya selama sepuluh tahun menjadi anggota legislatif baik di kota, kabupaten maupun provinsi. Untuk mengikis kebiasaan-kebiasaan yang kurang sehat Lalu Suryade menerapkan prinsip amar maruf 
nahi mungkar.

Transformasi nilai-nilai yang diterapkan oleh FPKS tidak jarang berbenturan dengan nilai-nilai dari fraksi lain. Hal tersebut dilatarbelakangi oleh perbedaan persepsi yang diterjemahkan oleh anggota legislatif dari fraksi yang berbeda. Dari wawancara 20 Oktober 2009 dengan Nur Supriyanto beliau berpendapat benturan tersebut terjadi dikarenakan kekhawatiran dari fraksi lain jika banyak ide atau pendapat yang muncul dari kalangan kami akan lebih memopulerkan salah satu fraksi. Jika salah satu bendera lebih membumi maka persepsi dari bendera yang lain akan mengecilkan mereka. Jika dikaitkan dengan teori interaksi simbolik Charles Horton Cooley (Soeprapto: 2001) menyebutkan semua interaksi antar individu manusia melibatkan pertukaran simbol. Salah satu strategi yang diterapkan yaitu ketika berinteraksi menggunakan simbol-simbol didalamnya berisi tanda-tanda, isyarat dan kata-kata bahasa yang bisa dipahami oleh mereka.

Praktik di lapangan dalam menransformasikan nilai-nilai ideologi FPKS mengalami kendala. Salah satu contoh kasus yang didasarkan pada wawancara 12 Oktober 2009 dengan Hj. Diah Nurwitasari, Dipl, Ing. adalah ketika terjun di dalam politik praktis dalam menjalankan aktivitas dakwah mereka, FPKS ingin menertibkan gratifikasi. Contoh kecilnya pemberian amplop-amplop oleh kepala dinas kepada anggota parlemen ketika pelaksanaan rapat. FPKS sedikit demi sedikit ingin menghapuskan kebiasaan tersebut. Karena FPKS mempunyai prinsip segala sesuatunya yang diterima anggota legislatif harus aman secara syari atau halal, aman secara legal formal atau secara hukum positif diperbolehkan, yang terakhir aman secara kepatutan. Jika hal-hal tersebut tidak terpenuhi maka anggota parlemen harus menolaknya.

Transformasi nilai-nilai yang diterapkan oleh FPKS tidak jarang berbenturan dengan nilai-nilai dari fraksi lain. Hal tersebut dilatarbelakangi oleh Perbedaan persepsi yang diterjemahkan oleh anggota legislatif dari fraksi yang berbeda. Dari wawancara dengan Nur Supriyanto pada tanggal 20 Oktober 2009, beliau berpendapat benturan tersebut terjadi dikarenakan kekhawatiran dari fraksi lain jika banyak ide atau pendapat yang muncul dari kalangan mereka akan lebih mempopulerkan salah satu fraksi. Jika salah satu bendera lebih membumi maka persepsi dari bendera yang lain akan mengecilkan mereka.

Strategi yang lebih menekankan pada konten atau esensi daripada konteks terbukti berhasil. Hal tersebut diterapkan karena orang terkadang sudah apriori terlebih dahulu jika melihat judul. Hj.Diah Nurwitasari, Dipl, Ing wawancara pada tanggal 12 Oktober 2012, mengatakan sebuah nilai tidak perlu diberi judul dengan kata-kata berbau Islam padahal di dalamnya semua hal yang dipraktikkan di dasarkan pada prinsip-prinsip Islam.

George Herbert Mead dalam Soeprapto (2001) memandang bahwa interaksionisme simbolik merupakan konstruksi dari beberapa pengertian tentang diri sendiri, tindakan, objek, dan sebagainya. Strategi yang dipakai oleh Hj.Diah Nurwitasari, Dipl, Ing jika mengacu pada teori tindakan dari Mead yaitu manusia menghasilkan karakter yang berbeda sebagai hasil dari bentukan proses interaksi dalam dirinya sendiri. Untuk bertindak, seorang individu harus mengetahui terlebih dahulu apa yang ia inginkan. Dia harus berusaha menentukan tujuannya, menggambarkan arah tingkah lakunya, memperkirakan situasinya, mencatat dan menginterpretasikan tindakan orang lain, mengecek dirinya sendiri, menggambarkan apa yang akan dilakukan dengan faktor-faktor lain.

Mead ingin menyimpulkan bahwa manusia dipandang sebagai organisme aktif yang memiliki hak-hak terhadap objek yang ia modifikasikan. Buktinya para FPKS tidak serta-merta mengamini semua tradisi yang mereka tidak yakini. Dari hasil wawancara dengan semua informan mengatakan kondisi birokrasi saat ini masih jauh dari kata ideal. Perlu waktu untuk sedikit demi sedikit dilakukannya pembenahan ke arah yang lebih baik. Jika ada sesuatu hal yang kurang sreg di hati maka para kader akan berkonsultasi kepada dewan syuro PKS. Tindakan manusia sendiri tidak semata-mata sebagai reaksi 
biologis, melainkan hasil konstruksinya. Tindakan dipandang sebagai tingkah laku yang dibentuk oleh pelaku, sebagai ganti respon yang didapat dari dalam dirinya.

Sistem politik yang sehat diimplementasikan juga dengan cara konsolidasi pimpinan baru yang amanah, profesional, bersih dari unsur-unsur lama. Langkah-langkah besar digariskan oleh PKS untuk secepatnya diwujudkan, yakni: Pertama, menyehatkan kehidupan lembaga legislatif sehingga optimalnya fungsi DPR/DPRD dan mengartikulasikan kepentingan rakyat, memproduksi undangundang/peraturan daerah, menetapkan anggaran, dan mengontrol jalannya pemerintahan. Kedua, mewujudkan fungsi keteladanan lembaga kedewanan dan kepartaian terutama dalam pemberantasan $\mathrm{KKN}$, termasuk di dalamnya akan mengusut tuntas segala macam penyelewengan yang telah dilakukan oleh anggota DPR/DPRD pada periode sebelumnya Ketiga, membentuk pemerintahan yang konsisten terhadap cita-cita reformasi dengan mengedepankan kehidupan sederhana bagi pejabat negara, konsisten dalam bertindak, menjalankan program yang riil menyentuh rakyat, dan menindak menteri-menteri yang bekerja tidak dijalur profesional. (Minardi Anton, 2008).

\section{Pemimpin Harus Peduli}

Para kader yang terjun di dalam politik praktis menganggap dirinya bukan sebagai wakil rakyat tetapi sebagai pelayan ummah (rakyat). Maka dari pelayan ummah harus peduli terhadap nasib rakyat yang diwakilinya. Ketika penulis diizinkan bertemu dengan Eka Hadian di kantor fraksi PKS, pada periode yang lalu yaitu 2004-2009 beliau terpilih menjadi ketua fraksi. Beliau menjelaskan keterlambatannya karena terjebak macet, juga karena kendaraan umum yang ditumpanginya "ngetem" sampai berjam-jam. Penulis kagum dengan kesederhanaan Eka Hadian yang masih menggunakan kendaraan umum ketika hendak pergi ke tempat dinasnya. Dalam pernyataannya (wawancara 9 Oktober 2009) ia berkata :

"Karena identitas saya sebagai pelayan ummah, maka tidak mungkin kehidupan saya lebih mewah dibandingkan dengan masyarakat yang harus saya layani “

Sebelum meleburkan diri ke dalam politik praktis, PKS banyak terlibat dalam kegiatan sosial, seperti pelayanaan kesehatan gratis untuk masyarakat yang kurang mampu, sembako murah, khitanan massal, membantu korban gempa atau yang terkena musibah dll. Ketika para kader memutuskan untuk mendirikan partai secara otomatis kegiatan sosial tidak terhenti.

\section{Pemimpin Harus Profesional}

Abad ke-21 merupakan abad di mana setiap orang harus menjunjung nilai profesional. Tidak ada lembaga dan organisasai manapun maju tanpa di dalamnya didukung oleh orang-orang yang bisa bertindak secara profesional. Berkaitan dengan profesional Allah SWT memerintahkan hambaNya untuk bertindak dan bekerja secara ihsan (baik) dan memberikan penghargaan yang lebih tinggi kepada hamba yang berlaku ihsan. "Dan berbuat baiklah, karena sesungguhnya Allah menyukai orang-orang yang berbuat baik (Al-Baqoroh: 195). Nur Supriyanto menjelaskan sikap profesionalisme beliau sebagai berikut:

"Dengan menunjukkan kesempurnaan
dalam bekerja, kita harus bekerja
tuntas, bekerja sempurna, bekerja
simpel dan mempunyai dasar dalam
menjalankan suatu pekerjaan yang
diembankan kepada kita."

Sikap profesionalisme dari para kader seperti yang dicontohkan oleh Lalu Suryade memberikan sikap yang dapat dipercaya, bekerja tanpa pamrih, menaati semua peraturan di parlemen. Misalnya setiap anggota fraksi harus mengikuti rapat fraksi serta rapat komisi. Dengan menuruti semua 
peraturan secara otomatis kita bisa memperlihatkan kinerja. Banyak anggota dewan yang tidak hadir ketika rapat komisi dan lebih banyak melibatkan diri pada studi banding. Alasannya karena studi banding lebih menguntungkan secara finansial. Maka dari itu untuk rapat komisi banyak anggota dewan yang mangkir sehingga rapat komisi yang lebih penting dari studi banding sering kosong.

\section{Filosofi Dalam Nama Partai Keadilan Sejahtera}

Partai harus dijadikan wadah untuk mempraktekkan slogan bersih, peduli dan profesional. Dahulu orang aneh dengan aktivitas partai keadilan yang sering melakukan bakti sosial, pelayanan kesehatan. Ketika itu tidak ada partai yang melakukan aktivitas seperti aktivitas Partai Keadilan Sejahtera. Kadang-kadang ada orang yang berceloteh PKS adalah ORMAS. Tetapi apabila kita lihat pada saat sekarang tidak ada partai manapun yang tidak melakukan aktivitas sosial. Dan untuk masyarakat umun yang melihat fenomena tersebut, sepertinya sudah biasa jika melihat partai yang melakukan aktivitas sosial. Sedangkan menurut Budi Widuri, partai adalah yang segala aktivitasnya ditujukan untuk kemaslahatan umat, tidak terkungkung pada kepentingan kelompok partai saja. Intinya adalah rahmatan lilalamin (wawancara 20 Oktober 2009).

Dalam wawancara dengan Nur Supriyanto, berpendapat, keadilan, sebagai salah satu prinsip dan doktrin politik Islam ialah pandangan yang menegaskan tentang kesatuan manusia. Islam memandang bahwa manusia diciptakan dari asal yang satu. Keadilan membuka jalan bagi nilai-nilai kebenaran, kebaikan, ketakwaan, keindahan, dan kebahagiaan. Keadilan bukan hanya menyediakan ruang bagi setiap orang untuk mendapatkan hak-hak asasinya sebagai manusia tetapi mewadahi semua potensi inovasi dan kreativitasnya. Keadilan menebarkan rasa aman dan membebaskan manusia dari semua bentuk intimidasi dan rasa takut. Kata tersebut disesuaikan dengan posisi yang kita bangun. Dahulu pada tahun 1999 nama partai bernama Partai Keadilan, kemudian setelah 2004 menjadi Partai Keadilan Sejahtera, itu disesuaikan dengan kondisi masyarakat kita yang masih jauh dengan kesejahteraan. PKS ingin memberikan kesejahteraan. PKS ingin meningkatkan kesejahteraan masyarakat. Tugas para kader di parlemen adalah bagaimana mengemban tugas membawa masyarakat untuk lebih sejahtera. Jika jauh dari sejahtera Nabi Muhammad SAW mengatakan akan mengantarkan pada kekufuran.

\section{Bentuk Komunikasi Non Verbal Anggota FPKS di DPRD Provinsi Jawa Barat.}

\section{Jilbab Merupakan Identitas bagi Politikus Muslimah}

Dalam beraktivitas publik (politik), seorang muslimah harus tetap memerhatikan rambu-rambu syari. Misalnya peraturan dalam menutup aurat. Persyaratan yang harus dipenuhi adalah menutup aurat dan mengenakan jilbab sahu untuk dipakai, dari penuturan informan serta dari buku pengaderan PKS antara lain sebagai berikut :

- Busana (jilbab) harus menutupi seluruh tubuhnya selain yang dikecualikan (tangan dan telapaknya serta wajah), bagian leher bagian depan sampai dada atas. Pada kombinasi jilbab gaul juga harus tertutup, begitu juga bagian leher belakang/tengkuk leher juga harus tertutup rapat, kaki tertutup, termasuk dari mata kaki ke bawah, bagian tangan tertutup hingga batas pergelangan telapak tangan.

- Busana yang bukan untuk perhiasan kecantikan, atau tidak berbentuk pakaian aneh yang menarik perhatian dan tidak berparfum sangat menyengat sekitarnya.

- Tidak tipis sehingga tampak bentuk tubuhnya

- Tidak sempit sehingga tampak bentuk tubuhnya

- Busana yang tidak menampakkan betisnya/kakinya atau celana panjang yang membentuk kakinya atau yang buntung celana panjangnya dan harus 


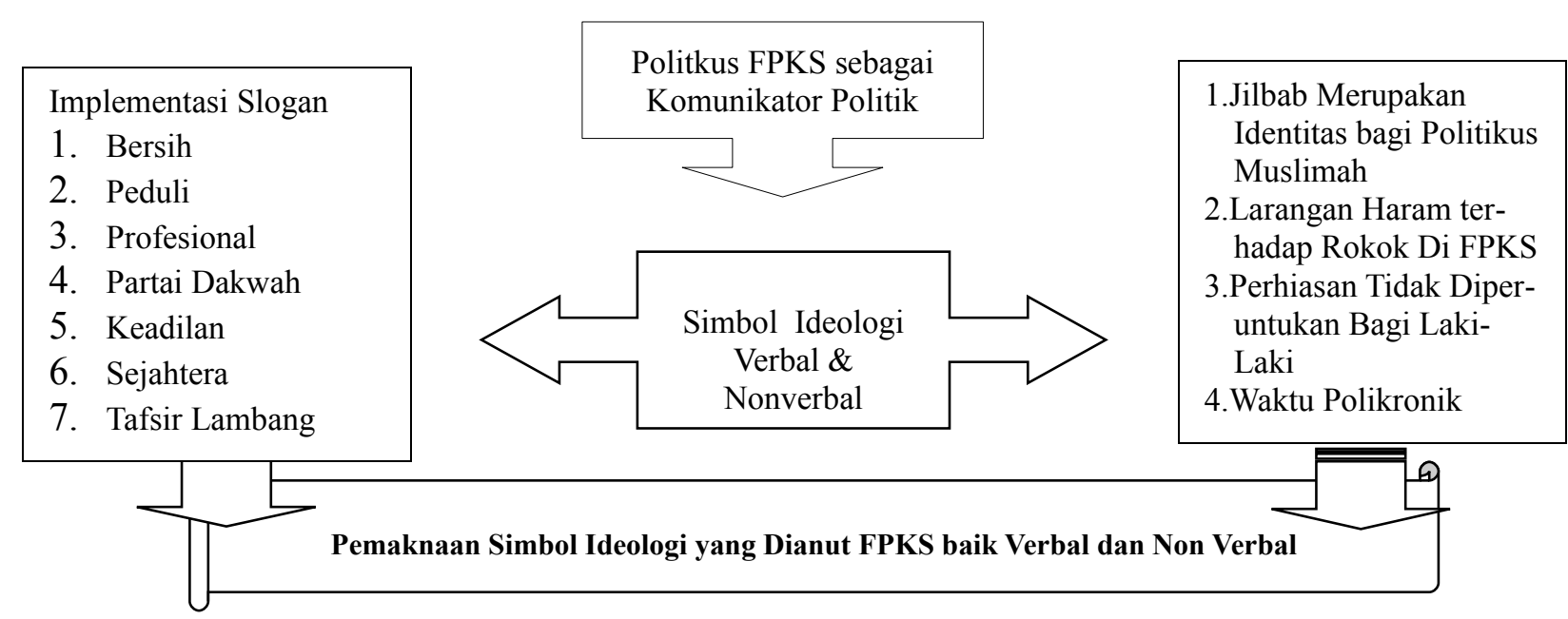

Sumber : hasil penelitian 2009

\section{Gambar 1}

\section{Model Implementasi Simbol-Simbol Ideologi FPKS Verbal Dan Nonverbal Di DPRD Provinsi Jawa Barat.}

\section{menutup sampai mata kakinya \\ - Tidak menampakkan rambutnya walaupun sedikit dan tidak pula lehernya walaupun sedikit terlihat \\ - Busana yang tidak menyerupai pakaian laki-laki dan tidak menyerupai pakaian wanita-wanita yang tidak islami}

\section{Larangan Haram terhadap Rokok di FPKS}

Dari wawancara dengan anggota FPKS yang laki-laki mereka mengaku tidak merokok dan mengharamkan rokok. Anggota dewan di beberapa tempat mencoba untuk mengesahkan RUU antirokok. Eka Hadian dalam wawancaranya mengatakan ruangan kami adalah ruangan bebas asap rokok, setiap anggota dari FPKS tidak merokok. Jika berkunjung ke kantor fraksi lain kita akan manjumpai beberapa anggota legislatif yang merokok, beberapa fraksi sengaja menyediakan asbak rokok dan terkadang kantor fraksi mereka bau asap rokok. Merokok bagi sebagian orang dinilai sebagai gaya hidup, sehingga tak bisa membiarkan hari-hari lepas tanpa merokok. Namun bagi sebagian orang lainnya menganggap merokok merupakan perbuatan sia-sia yang hanya berujung pada bersarangnya penyakit dalam tubuh.
Perhiasan Tidak Diperuntukkan Bagi LakiLaki

Selain bertemu serta terlibat dalam pembicaraan baik formal atau nonformal dengan FPKS, penulis terlibat pembicaraan dengan beberapa anggota Fraksi Demokrat, PDIP, Golkar, PKB serta Hanura. Ada sebuah perbedaan antara FPKS dengan fraksi bila dilihat dari penampilan. Setiap anggota di fraksi PKS tidak memakai cincin emas dengan dibubuhi batu permata, jam tangan emas dan permata atau sepatu kulit dengan perhiasan batu permata. Ketika peneliti memberikan pertanyaan seputar penggunaan perhiasan bagi kaum laki-laki menurut anggota FPKS beranggapan para lelaki yang ingin tampil modis boleh-boleh saja memakai pakaian apa saja yang disukainya, selama itu masih sesuai dengan norma dan syariah agama Islam. Dan yang perlu diingatkan lagi, selain kain sutera, agama juga melarang kaum pria untuk memakai perhiasan emas.

\section{Inkonsistensi Para Wakil Rakyat Terhadap Waktu (Waktu Polikronik)}

Budaya ngaret alias tidak tepat waktu sering dilakukan oleh anggota legislatif di DPRD Provinsi Jawa Barat. Inkonsistensi waktu kerap terjadi pada saat rapat fraksi, 


\section{Tabel 1}

Hasil Konstruksi Konsep George Herbert Mead

\section{KONSTRUKSI PEMIKIRAN \\ NO PEMIKIRAN HERBERT MEAD

\author{
ANGGOTA LEGISLATIF FPKS DALAM MENGONTRUKSIKAN \\ PEMIKIRAN MEAD
}

$1 \quad$ Diri sendiri

a. ketika anggota dewan memasuki masa reses mereka mulai menyusun strategi, menyusun jadwal serta mempersiapkan diri untuk tampil di depan masyarakat. Is Budi Widuri beranggapan jika reses dilakukan pada majelis talim akan lebih efektif mengingat jemaah yang datang berasal dari latar belakang usia, profesi serta strata yang berbeda-beda.

b. Diah Nurwitasari berkunjung ke beberapa tempat di daerah pemilihannya. Tempat yang dipilih merupakan tempat yang didominasi oleh pemilihnya. Hal tersebut dilakukan untuk menggalang simpati pemilih serta diharapkan pemilih akan memberikan suaranya pada pemilihan legislatif selanjutnya.

c. Interaksi dilakukan dengan masyarakat sekitar dengan mempertimbangkan beberapa aspek semisal apa yang menjadi harapan dan keinginan setiap masyarakat. Di akhir pertemuan ia mengatakan setiap aspirasi akan ditampung yang kemudian dikomunikasikan dalam rapat-rapat.

\begin{tabular}{ll}
\hline Tindakan & Interaksi yang terjadi di lingkungan dewan melibatkan pertukaran makna. \\
& Pertukaran makna diterjemahkan dari sikap, perbuatan, dan tindakan. \\
b. & Tiap fraksi memiliki pemahaman yang berbeda dalam menerjemahkan uang \\
& insentif (amplop). Ada yang menerimanya dan ada yang menganggap tidak \\
& boleh. \\
c. & FPKS beranggapan parlemen terlalu budget oriented. Menurut sebagian \\
& anggota FPKS hal tersebut menghambat kreativitas anggota dewan. Yang \\
& lainnya beranggapan mustahil menjalankan program tanpa adanya anggaran. \\
\hline Objek & Anggota fraksi PKS memaknai kedudukan sebagai anggota dewan \\
& merupakan suatu amanah yang berat. Menjadi anggota dewan bukanlah \\
& merupakan prestise. Jika harus memilih maka anggota legislatif PKS akan \\
& memilih berdakwah di jalur lain. Tanggung jawab sebagai anggota dewan \\
& berkonsekuensi dengan kewajiban untuk menyalurkan aspirasi masyarakat \\
& serta aktivitas dakwah di parlemen. \\
b. Anggota dewan memilih berdakwah dengan sikap serta perbuatan \\
dibandingkan dengan perkataan. Karena dengan memberikan akhlak yang \\
terpuji akan lebih mengefektifkan aktivitas dakwah. \\
c. Pemilihan sebagai ketua fraksi atau wakil ketua fraksi ditentukan oleh \\
kapasitas selama mereka berkiprah di lingkungan internal partai.
\end{tabular}

$5 \quad$ Aksi Kolektif

a. Anggota legislatif dari FPKS ketika terpilih mencoba untuk menyesuaikan diri dengan lingkungan sekitar. Penyesuaian tersebut karena adanya perbedaan aktivitas dakwah antara ranah politik praktis dan masyarakat.

b. Menurut FPKS birokrasi di Indonesia menjadi sarang KKN. Jika ada benturan antarvisi dan misi antar partai FPKS mencoba untuk bersifat kompromi atau tidak kompromi.

c. FPKS beranggapan butuh waktu untuk menyadarkan lingkungan sekitar akan prinsip yang ada dalam agama islam strategi dilakukan dengan melakukan pendekatan personal dan sosial. 
komisi, paripurna dan kegiatan reses. Waktu Polikronik dianut oleh hampir semua anggota DPRD Provinsi Jawa Barat. Penganut waktu polikronik menganggap bahwa waktu bersifat sirkular atau konsep waktu daur ulang. Kontras dengan waktu linier, waktu daur ulang dianggap sebagai waktu yang mengulangi dirinya sendiri. Maka keterlambatan atau kelalaian untuk melakukan suatu pekerjaan merupakan hal yang dianggap biasa.

\section{PENUTUP}

\section{Simpulan}

Implementasi simbol ideologi FPKS dikomunikasikan baik secara verbal dan nonverbal. Simbol ideologi verbal FPKS di DPRD Provinsi Jawa Barat adalah mengimplementasikan slogan Bersih, Peduli, Profesional, Partai Dakwah, Keadilan, Sejahtera. Sedangkan menerjemahkan simbol ideologi berupa nonverbal antara lain Jilbab merupakan identitas bagi politikus muslimah, Jenggot simbol dari sunnah bagi FPKS, Larangan Haram terhadap Rokok di FPKS, musik murotalan alunan penyejuk hati, perhiasan tidak diperuntukan bagi laki-laki, inkonsistensi waktu (Waktu Polikronik). Kiprah anggota legislatif FPKS di DPRD Provinsi Jawa Barat dalam mengemban misi dakwah jika dikaitkan dengan konsep interaksi simbolik George Herbert Mead tentang dirinya sendiri, tindakan, objek, interaksi sosial dan aksi kolektif.

Anggota DPRD Provinsi Jawa Barat Fraksi PKS dan juga anggota fraksi yang lainnya diharapkan lebih mempunyai disiplin terhadap waktu, mengingat mereka adalah figur atau panutan masyarakat serta memiliki tugas untuk mengawasi pemerintah provinsi. Jika fungsi pengawasan yang mereka emban tidak dilakukan dengan tepat waktu maka akan berpengaruh pada kinerja. Serta kapabilitas sebagai anggota dewan.

\section{Saran}

Anggota DPRD Provinsi Jawa Barat Fraksi PKS diharapkan bisa lebih memberikan warna bukan sekedar mewarnai dalam setiap kiprah di parlemen. Konsistensi terhadap prinsip-prinsip yang mereka yakini untuk berdakwah lebih dipertegas dengan cara memberikan contoh yang baik. Diharapkan anggota dapat meyakinkan anggota legislatif lainnya baik di rapat komisi, pansus, dan paripurna perihal semua hal yang berkaitan dengan kepentingan masyarakat.

\section{DAFTAR PUSTAKA}

Minarsi Anton, (2008). Konsep Negara dan Gerakan Baru Islam, Menuju Negara Modern Sejahtera. Bandung : Prima Press Prodaktama.

Mulyana, Deddy. (2002). Ilmu Komunikasi Suatu Pengantar. Bandung: Remaja Rosdakarya.

Moleong, Lexy. (2000). Metodologi Penelitian Kualitatif. Bandung : Remadja Rosdakarya

Miles, Matte B dan A, Michael Huberman. (1992). Analisis Data Kualitatif. Penterjemah Rohendi Rosidi. Jakarta :UI Press.

Orleans, Myron, (2000), Phenomenology, dalam Kumpulan Bahan Mata Ajaran Metodologi Penelitian Kualitatif oleh Daniel T. Sparringa, FISIP Unair.

Sumarno dan Harun, (2006). Komunikasi Politik Sebagai Suatu Pengantar. Bandung : Mandar Maju

Sukidin dan Basrowi, (2002). Metode Penelitian Kualitatif Perspektif Mikro.

Surabaya : Insan Cendikia

Soeprapto Riyadi, (2002), Interaksi Simbolik: Yogyakarta :Averroes Press.

Suprayogo, Iman dan Tobroni. (2001). Metodologi Penelitian Sosial-Agama. Bandung : PT Remaja Rosda Karya 


\section{Surat Kabar:}

Pikiran Rakyat edisi, 14,15,16,17,18 Mei 2009. 